\title{
Stranger Than Fiction: Gothic Intertextuality in Shakespears Sister's Music Videos ${ }^{1}$
}

\section{ABSTRACT}

The following article is going to focus on a selection of music videos by Shakespears Sister, a British indie pop band consisting of Siobhan Fahey and Marcella Detroit, which rose to prominence in the late 1980s. This article scrutinizes five of the band's music videos: "Goodbye Cruel World" (1991), "I Don't Care" (1992), "Stay" (1992), "All the Queen's Horses" (2019) and "When She Finds You" (2019; the last two filmed 26 years after the duo's turbulent split), all of them displaying a strong affinity with Gothicism. Fahey and Detroit, together with director Sophie Muller, a long-time collaborator of the band, have created a fascinating world that skillfully merges references to their tempestuous personal background, Gothic imagery, Hollywood glamour and borrowings from Grande Dame Guignol, a popular 1960s subgenre of the horror film. Grande Dame Guignol is of major importance here as a genre dissecting female rivalry and, thus, reinterpreting a binary opposition of the damsel in distress and the tyrant, an integral element of Gothic fiction. Therefore, the aim of the article is not only to trace the Gothic references, both literary and cinematic, but also to demonstrate how Shakespears Sister's music videos reformulate the conventional woman in peril-villain conflict.

Keywords: Gothicism, intertextuality, Shakespears Sister, female rivalry, Grande Dame Guignol, music video.

1 This article was developed as part of the project entitled Word, Sound and Image: Intertextuality in Music Videos no. 2019/33/B/HS2/00131 financed by National Science Centre in Poland. 
Discussing the notion of female rivalry in Shakespears Sister music videos would not be possible without going back to the mid- $18^{\text {th }}$ century when the Gothic movement started to grow in popularity. What started as an initial fascination with the Middle Ages, not infrequently (though inaccurately) termed the Gothic times, and, subsequently, archeology and architecture, led to the birth of a particular literary genre, i.e. the Gothic novel. Fred Botting observes the genre's intertextual underpinnings and notes: "A hybrid form from its inception, the Gothic blend of medieval and historical romance with the novel of life and manners was framed in supernatural, sentimental or sensational terms" (44-45). These sensational elements would usually embrace

a mysterious crime, usually of an illicit or incestuous nature; a villain who in many cases has pledged himself to diabolical powers; persecuted maidens or fatal, Medusa-like women; charnel houses, tombs and graveyards; and nature itself conspiring to produce effects of gloomy terror. (Phelps 110-11)

Early Gothic texts eagerly juxtaposed the above mentioned "persecuted maidens" with tyrannical male oppressors, thereby developing a dynamic binary opposition that would usually form the narrative backbone of each novel. Horace Walpole's The Castle of Otranto (1764) originated the trend and paved the way for numerous followers, with Ann Radcliffe and Matthew Gregory Lewis among the most prominent ones. Initially, Walpole's model of a Gothic novel was strictly observed in terms of structure and characterization. From the $19^{\text {th }}$ century onwards, however, Gothic texts gained more intricacy and insightfulness, and the seminal damsel in distressvillain pairing underwent significant changes. More and more frequently, both roles would be assumed by female characters, turning Gothic narratives into interesting analyses of complex relations among women. An early example of such a novel is Charlotte Dacre's Zofloya, or The Moor (1806).

Undoubtedly, from its outset, Gothicism was an integral part of what one could nowadays call popular culture. With the growing readership in the latter half of the $18^{\text {th }}$ century, Gothic fiction reached a broad audience, even to the point of oversaturation: "[i] $\mathrm{t}$ had fallen into the hands of unskilled, imitative writers: the result was either that the repetition of horrors in vulgar copies of Lewis blunted appetites, or that the dependence on Radcliffe-type explanations became tedious" (Hennessy 335). Fortunately, novels such as Mary Shelley's Frankenstein; or, The Modern Prometheus (1818), Emily Brontë's Wuthering Heights and Bram Stoker's Dracula (1897) contributed to the Gothic revival. At the end of the $19^{\text {th }}$ century, Gothicism successfully transitioned to a new medium, that of cinema; the 
first Gothic-themed short films appeared as early as the 1890s, with Le Manoir du diable (The House of the Devil), an 1896 production by Georges Méliès, being a primary example. Horror as a separate genre went through several stages of development in the $20^{\text {th }}$ century. The $1920 \mathrm{~s}$ and $1930 \mathrm{~s}$ films derived inspiration mainly from the classic literary texts or their stage adaptations, ${ }^{2}$ as well as folk tales. ${ }^{3}$ Then, the audience was confronted with a new fad of the so-called monster movies in the 1940s and 1950s, ${ }^{4}$ where the post-WW2 "red scare" and atomic conflict contributed to the Gothic atmosphere of doom and gloom. From the 1960s onwards, more and more horror films exploited the motif of a (usually male) psychopathic stalker and his gruesome murders, which was a modernized rewriting of the perennial woman in peril-tyrant conflict (e.g., Alfred Hitchcock's 1960 Psycho, based upon Robert Bloch's 1959 novel of the same name, or Michael Powell's Peeping Tom, also 1960). The 1960s brought to the fore one more new subgenre of horror, i.e. Grande Dame Guignol, also known as hag horror, hagsploitation movement or psycho-biddy. ${ }^{5}$ As it turned out, this subgenre would have a lasting influence not only on cinema in general, but on the music video, as well.

Indeed, the 1970s and 1980s open a new chapter in the history of Gothicism. Increasingly, music videos not only depicted musicians performing their songs. On the contrary, they developed into entities of their own, ensuring that they would eventually become "a mandatory tool in the marketing of music" (Cameron) and signifying a new type of interdependence between the lyrical and the visual content. As Will Straw puts it,

[t] he relationship of song to visuals [was] obviously not simply one of narrative or visualization ..., but rather one between the basic demands of form (some elaboration of proposed themes, a movement towards closure) and the hetereogeneity of codes and visual materials held in play by that form. (258)

2 The apt examples are F. W. Murnau's masterpiece of German Expressionism, Nosferatu: A Symphony of Horror (1922), which was an unauthorized screen adaptation of Stoker's classic, as well as James Whale's Frankenstein (1931), based on Peggy Webling's play, or Dracula (1931) by Tod Browning, inspired by a 1924 play by Hamilton Deane and John L. Balderston.

See, for instance, Paul Wegener's The Golem: How He Came into the World (1920).

4 Among them one could mention Jacques Tourneur's Cat People (1942) and its 1944 sequel, The Curse of the Cat People, but also Arthur Hilton's Cat-Women of the Moon (1953), It Came from Outer Space (1953) and Creature from the Black Lagoon (1954), both directed by Jack Arnold, Don Siegel's Invasion of the Body Snatchers (1956) or Irvin Yeaworth's The Blob (1958).

5 For an extensive discussion of the genre's history, see Peter Shelley's 2009 Grande Dame Guignol Cinema: A History of Hag Horror from "Baby Jane" to "Mother." 
A number of music videos directly incorporated Gothic elements such as settings or characters, creatively revamping them. ${ }^{6}$ Kate Bush's "Wuthering Heights" (1978) and "Hammer Horror" (1980) respectively paid tribute to Emily Brontë's novel and the notorious British film studio specializing in bloody and highly eroticized adaptations of literary Gothic classics. Sheena Easton's "Telephone (Long Distance Love Affair)" (1983) drew heavily upon Mary Shelley's Frankenstein. Meat Loaf's "If You Really Want To" (1983) and Pet Shop Boys' "Heart" (1987) played with vampire imagery. Without a doubt, the rise of a new music genre called Gothic Rock also fuelled the development of Gothic music videos. Nevertheless, it would be shortsighted to conclude that the Gothic in music videos is limited to just one genre and a selection of bands associated with it (The Cure, The Sisters of Mercy, Bauhaus, Fields of the Nephilim or Siouxsie and the Banshees). The case of Shakespears Sister's visual output proves that Gothic intertexts, both literary and cinematic, permeate a significant portion of the (indie) pop scene, too.

Several of Shakespears Sister's music videos owe a lot to both the Gothic tradition and one of its cinematic offshoots, i.e. Grande Dame Guignol. Conflicts would always propel the action in the Gothic texts, as exemplified by the aforementioned damsel-villain opposition that kept developing throughout the centuries. Grande Dame Guignol also mobilized this characteristic Gothic element, ascribing both roles to women. The premiere of Robert Aldrich's What Ever Happened to Baby Jane? in 1962 started a cinematic trend which would portray women, usually middle-aged, at a critical moment of their lives and focus on their mental imbalance, traumas, social exclusion and, most of all, conflicts, especially with other women. ${ }^{7}$ Quite ironically, the rivalry applied both to film characters and the actresses cast in these roles, the majority of them starring as leads after a prolonged hiatus. Despite its grotesque excess and uninhibited campness, Grande Dame Guignol still offered a convincing portrayal of the female condition set against a Gothic background. Soon, numerous imitations followed, among them Hush... Hush, Sweet Charlotte (1964, dir. Robert Aldrich), Strait-Jacket (1964, dir. William Castle), Die! Die! My Darling! a.k.a. Fanatic (1965, dir. Silvio Narizzano) and What

6 According to Michael Shore, music videos "mirror and extend popular culture" (99). Therefore, if one takes into consideration the impact of Gothicism on popular culture, one can agree that rewriting Gothic conventions would be an instance of such extension and enhancement.

7 For a more thorough discussion of Grande Dame Guignol as a narrative of trauma, see Fisiak "What Ever Happened to My Peace of Mind? Hag Horror as Narrative of Trauma" or "Grande Dame Guignol and the Notion of the Aftermath: A Case Study of Robert Aldrich's Hush ... Hush, Sweet Charlotte (1964).” 
Ever Happened to Aunt Alice? (1969, dir. Lee H. Katzin). Although the generic formula quickly wore off and by the mid-1970s hagsploitation had practically disappeared, it soon became a source of inspiration for filmmakers and musicians alike, as this article will demonstrate. The oeuvre of Shakespears Sister is a case in point. The analysis is going to concentrate on five of the band's music videos, three of which, i.e. "Goodbye Cruel World" (1991), "I Don't Care" (1992) and "When She Finds You" (2019; recorded 26 years after the duo's turbulent split), display a close affinity with hag horror, in particular Aldrich's What Ever Happened to Baby Jane? On the other hand, "Stay" (1992) and "All the Queen's Horses" cleverly deconstruct Gothic conventions regarding setting, characters and their mutual relations. All five of the videos skillfully rewrite Gothic elements, merging tradition with Hollywood glamour and, most of all, adding a new twist to the seminal pairing of woman in peril and vindictive tyrant.

As mentioned before, in hag horror, a neo-Gothic tyrant usually assumes the shape of a mentally unbalanced woman in her 50s. The role of damsel in distress is shifted onto her female kin-a sister, a mother, a daughter, a cousin. Some hag productions exploit different types of conflicts between two female protagonists, focusing on mothers- and daughters-in-law or close friends instead. In What Ever Happened to Baby Jane?, starring two silver screen legends, Joan Crawford and Bette Davis, the plot revolves around an ongoing conflict between the Hudson sisters, former actresses. Jane (Davis) was a child star, while Blanche (Crawford) gained fame as an adult. Jane's nasty behaviour towards Blanche in their childhood, followed by Jane's decline in popularity and her subsequent addiction to alcohol, as well as Blanche's enormous success in Hollywood, put a strain early on in their relationship. Eventually, Blanche is injured in a car crash, the blame for which is put on Jane. The wheelchair-bound Blanche and mentally unstable Jane retire from the film industry altogether and cut themselves off from the outside world, immersing themselves in the world of mental and, eventually, physical violence. Aldrich's film seems to distribute the roles in a blatant way: "Initially we see Davis as the antagonist, tormenting her relatively normal but physically disabled protagonist sister Crawford" (Shelley 8). Later, however, the audience is confronted with an illuminating ending: "the climax reveals that Crawford became disabled when she tried to seek revenge on Davis when they were younger. This plot twist makes us re-evaluate Crawford as an antagonist and the revelation turns Davis into a passive child, victimized and insane" (Shelley 8-9). What surely added to the film's credibility was the reallife feud between the actresses: "[ $\mathrm{t}]$ heir rivalry was as intense as it was renowned, but it took until . . 1962 for the conflict between [them] to break out into the open" (Helmore). 
Similarly, conflicts define the history of Shakespears Sister, a BritishIrish/American indie pop band that rose to prominence in the late 1980s. The act started as a solo project of Siobhan Fahey, who was a member of the successful pop trio Bananarama between 1979 and 1988. Due to irreconcilable creative differences, Fahey left in 1988. In a TV interview with Mick Brown, she admitted that she was "sick of making that kind of music"; she found Bananarama too "glossy" and "polished" music-wise, while she intended to go in a more alternative direction ("I've always liked imperfection myself"). The name of her new project was inspired by a song by The Smiths, "Shakespeare's Sister," itself a reference to Virginia Woolf's A Room of One's Own. ${ }^{8}$ Fahey intended to stay solo. However, at the insistence of her then-husband, Dave A. Stewart, himself a significant figure in the music industry as one half of Eurythmics, and her record company, she was soon joined by Marcella Detroit (a.k.a. Marcy Levy), an established musician, who started her career in the 1970s, worked with numerous artists (Eric Clapton, Aretha Franklin and Chaka Khan, among others) and who had already released two albums (a solo one and a joint effort with Diane Reeves). In the end, Detroit co-authored a few songs on Sacred Heart, the group's debut album. She recalled in a 2005 interview with Michael Hubbard: "By the time we did the last song on the first album ... my role became more integral.... I was asked ... to become a 50\% member. I didn't just want to be a background singer," adding that from the start she was aware of Fahey's leader position in the duo: "It was Siobhan's band, this was made perfectly clear. But I was cool with that-that's the way it was." Unfortunately, a fruitful collaboration soon turned sour. The conflicts kept growing, especially fuelled by the enormous success of "Stay," the second single promoting their sophomore production, Hormonally Yours, which brought Detroit to the foreground, very much against Fahey's wishes. As Detroit explained in detail on her website:

I think Siobhan and I were very different people which we both came to find out. Unfortunately there were internal conflicts that could just not be resolved. From my perspective, the beginning of the end was when "Stay" became our biggest hit. As I mentioned above, Siobhan was not happy about the release of "Stay" as a single as she felt and said many times, "it does not represent Shakespears Sister."

After the cancellation of several shows, a spectacular break-up ensued. At the 1993 Ivor Novello awards, Fahey and Detroit were supposed to collect

8 Talking to Mick Brown, Fahey confessed that the misspelling was not deliberate at first, but that she decided to retain it, as it made it "her thing, as opposed to the song by The Smiths." It also remained in line with her penchant for "imperfection." 
a prize for Hormonally Yours. Although Fahey was absent, she asked the band's publicist to read a note on her behalf. "The acceptance speech instead became a farewell to her musical partner, with Siobhan wishing her a ruthlessly serene 'all the best for the future"' (Hanra), stunning not only Detroit, but also the audience and the music industry as such. Later on, Marcella Detroit recalled in one of the posts on her website:

There were lots of fights between us and considering it was supposed to be a wonderful time with lots of success, it was unfortunately filled with petty bickering and jealousies. I was accused of trying to steal the band away from her, ridiculed and pitted against constantly.

All in all, it took them almost 26 years to join forces again. ${ }^{9}$

It is unsurprising that their music videos often reflect the latent element of (near-Gothic) rivalry, although not much of it is detectable in those promoting their first album, Sacred Heart (1989). The first two, a circusinspired one for "Break My Heart (You Really)" and a runaway bride-themed one for "Heroine" (both 1988), do not even feature Marcella Detroit. She (and a vamp look for both bandmates) appears for the first time in 1989's "You're History." While the music video for "Run Silent"(1989) situates the two in a dreamy waterscape, creating an ekphrastic parallel with John Everett Millais's famous painting Ophelia (1851-52), the one for "Dirty Mind" returns to the singers' vamp image (black clothes, pale skin, lush red lipstick) and shows them performing against a backdrop of their previous music videos. ${ }^{10}$ Except for the last one, credited to The Craze Boys, all of the videos were directed by Sophie Muller, who became the band's long-lasting collaborator, holding responsibility for 13 out of the 22 music videos made to date by Shakespears Sister (both as a duo and Fahey's solo act). ${ }^{11}$

The situation changed with the music videos for Hormonally Yoursan album clearly influenced by cinema. As Imran Khan explains,

[o] riginally conceived as a concept album written as a sort of soundtrack to a schlocky 50 s-era B-film by Arthur Hilton called Cat-Women of the Moon, many of the songs' lyrical content was derived from the film's

9 "Fahey and Detroit discussed reuniting... during the summer of 2018 in London, after Fahey had done some reunion shows with Bananarama and Detroit performed with [Eric] Clapton in Hyde Park" (Graff). Fahey explained: "One [reunion] inspired the other, for sure. By doing the Bananarama thing, it was reconnecting with a part of myself that I had left behind-and there was another piece that I'd left behind [with Shakespears Sister] that I needed to connect to" (Parker).

10 The music video for "Sacred Heart" (1989) was excluded from this brief analysis, as it was specifically prepared for Dave A. Stewart's TV show, Beyond the Groove.

11 All five music videos to be scrutinized in this article are Muller's works. 
storyline. ${ }^{12}$ The band initially sought to secure the rights to the film in order to expand on the album's concept with planned music videos built directly on actual footage from the film. The idea was shot down by the record company.

Nevertheless, three out of the six music videos illustrating the album display a strong connection with cinema, referring to hag horror and the Gothic tradition as such. They are built around the idea of discord between their two protagonists, thus reflecting the real-life disagreements between Fahey and Detroit.

The most prominent example is "Stay," a Gothic tale taking place in a dark moonlit chamber filled with medical equipment, a mixture of a dark castle interior and a hospital ward. Detroit takes the role of a Gothic sister of mercy taking care of her comatose lover. Fahey appears mid-video as Death, who comes to take the man's soul. The two start a fight, in which life triumphs over death ${ }^{13}$-Detroit saves her lover, who miraculously regains consciousness. Fahey's Death leaves sneering in anger. The Gothic conflict exists on an aural level, as well. Małgorzata Grajter, a music theorist, explains that juxtaposing two completely dissimilar vocal registers is a Wagnerian trick, Marcella's high register connected with the celestial sphere, Siobhan's contralto associated with hell and darkness. Grajter also pays attention to the contrast in the very structure of the song. The introductory part (verse-chorus-verse-chorus) is a delicate pop ballad without a rhythm section, containing, however, ambient, sci-fi elements (which in itself is a nod to Elmer Bernstein's soundtrack for CatWomen of the Moon). Then, more or less at a 2:00 time stamp, Siobhan's bridge part with a riveting guitar riff and a pulsating rhythm section begins. Marcella's whistle register note (2:55 time stamp) overpowers the riff, signifying a symbolic reunion but one that, unfortunately, occurred only on a musical narration level; in the interview with Michael Hubbard, Marcella Detroit recalled: “In the video for 'Stay,' I was singing to this guy who was dying and she (Siobhan) was the Angel of Death. We used our personality differences to our advantage, but it was a little too real!" Grievances aside, "Stay" turned out to be a smash hit, becoming the act's only UK number one.

12 "Stay," "Moonchild" and "Catwoman" are the most outstanding examples.

13 Sophie Muller recreates a motif of psychomachia, so typical of Medieval morality plays. The mock-fight between Detroit and Fahey is reminiscent of the conflict between the allegorical Virtues and Vices in The Castle of Perseverance and looks as grotesque. The inclusion of excessive Gothic make-up, a sparkly catsuit on Fahey, not to mention the two leads' over-the-top gestures and facial expressions, characteristic of Grande Dame Guignol, add a camp quality to the video. 
The music video for "Goodbye Cruel World," as Gothic and gloomy as the one for "Stay," re-enacts Grande Dame Guignol camp aesthetics. ${ }^{14}$ Its first thirty seconds play with two classics: the aforementioned What Ever Happened to Baby Jane? and Billy Wilder's Sunset Boulevard (1950). Even though the latter does not really qualify as a hag horror, being more of an attempt at film noir, it surely bears a strong likeness to this genre, depicting "50-year-old, once-great silent film star Norma Desmond (Gloria Swanson), living in a rundown palazzo among the mementos of her past and plotting a 'return' in her own adaptation of Salome" (Shelley 10). Norma, a tragic screen diva, continues to live in an illusion that "the pictures got small," while she remained a grand star. Her fate is as poignant as the Hudson siblings'-she kills a man who was supposed to help her stage her triumphant comeback. Before she is transported to a mental facility, Norma is given one final chance to thrive in the limelight, descending the stairs at her lavish mansion, as if she were the actual Salome, enjoying the presence of photographers and journalists, and, most of all, declaring to Mr. DeMille, the director, her readiness for a close-up. The beginning of "Goodbye Cruel World" reinvents that scene. Before Siobhan Fahey announces that she is also ready for her close-up, we see the two in an upscale apartment, Fahey filing her fingernails and towering ominously over Detroit, who fiddles with her guitar. In one of the most iconic scenes in What Ever Happened to Baby Jane? Blanche complains to her sister: "You wouldn't be able to do these awful things to me if I weren't still in this chair," to which Jane brusquely responds: "But you are, Blanche! You are in that chair!" In Sophie Muller's modernized interpretation, with both characters much younger than their cinematic antecedents, it is Detroit who plays the unfavourable role of the victim, claiming that Fahey's character would not have been able to do those awful things to her if she had not been stuck behind that guitar. Detroit's reply is as cruel as Jane Hudson's: "But you are, Marcy! You are stuck behind this guitar!” From the outset, the music video relies heavily on camp aesthetics associated with the Golden Age of Hollywood, musicals in particular, "with their overthe-top moments of spectacle, robust color schemes, female stars taking center stage, overt theatricalization of gender roles" (Cohan). Fahey and Detroit manifest the "corny flamboyant femaleness" (Sontag 279) typical of Hollywood glamour through wearing fancy costumes (the former a black robe, dark glasses and a turban, the latter-a white fur and heavy

14 Susan Sontag notes that the origins of camp taste are to be found as early as the $18^{\text {th }}$ century, treating Gothic fiction as one of its emanations (280). For a more elaborate discussion of Grande Dame Guignol and camp sensibility, see Fisiak, "Hag Horror Heroines: Kitsch/Camp Goddesses, Tyrannical Females, Queer Icons.” 
jewellery), fake acting and excessive mannerisms. Many scenes portray them rolling on their grand beds and making dramatic facial expressions or exuberant gestures. To top it all, in certain scenes, the two are shown performing on a stage in their shimmering "moon" catsuits, reviving the original idea behind their second album. Imran Khan observes that Sophie Muller, aware of the tensions between Fahey and Detroit, "found a dazzling gimmick with which to sell the band's image," adding that

[h] er treatment for "Goodbye Cruel World" re-envisions the gothicglam rock palaver ${ }^{15}$ as a Hollywood drama, spoofing ${ }^{16}$ untouchable classics like Sunset Boulevard and Whatever Happened to Baby Jane? Detroit's Joan Crawford and Fahey's Bette Davis sweep and cavort around the black and white Victorian gloom.

According to Cazz Blase, the band's dark, yet glamorous image

was intriguing at the time because it went against the prevailing mood of the early nineties, as did the music. Dance flavoured pop was the dominant theme at the time, and goth and glam were both definitely out, so the presence of Shakespears Sister created a sense of discordance.

Combining Gothic discord with a particular Hollywood feel characterizes the video for "I Don't Care," as well.

This time, Muller depicts two women plotting against each other, their conflict set against a background strongly reminiscent of both 1920 s Art Deco and the Victorian era. The first scene portrays a fully made-up Marcella Detroit tormented by nightmare ${ }^{17}$ of Fahey performing without her. Their first face-to-face confrontation takes place in a sparsely lit corridor and the two look as if they were on the set of Jean-Luc Godard's 1965 Alphaville. The next scene shows the two at a table in their musicians' company. Both characters cast aggressive looks at each other and make intimidating faces. At one point, Detroit points a knife at Fahey, while

15 Małgorzata Grajter notices in "Goodbye Cruel World" direct references to the harmonic structure characteristic of Pink Floyd (effect achieved through the usage of $\mathrm{D}$ major and $\mathrm{G}$ major scales).

16 While "Goodbye Cruel World" can be considered a spoof of legendary Hollywood productions, Shakespears Sister music videos also became a relevant material for travesty, as demonstrated by "Dickens Daughters" (1993), a brilliant parody of "Stay" and "I Don't Care" by two British comediennes, Dawn French and Jennifer Saunders.

17 Philip W. Martin observes that "[i]n its sense of a distressing or disturbingly prescient dream, nightmare is a common device in Gothic fiction” (164), as testified by Walpole's Otranto or Radcliffe's fiction. The female protagonists of hag horrors also frequently suffer terrifying, elaborate dream visions-William Castle's Strait-Jacket and The Night Walker (1964) are representative cases. 
Fahey puts poison in Detroit's glass of wine and asks her to drink it. The way Detroit eats makes one think of a certain scene in What Ever Happened Baby Jane? in which Jane consumes a chicken leg in a savage, animalistic way. "I Don't Care" efficiently captures the emotional strain between the band members. In the video's final segment, Detroit wakes up in her bed only to see Fahey in a Victorian outfit reciting Dame Edith Sitwell's "Hornpipe" on a miniature stage, itself a surprising intertextual detail. A brief moment of reconciliation follows-Fahey reaches for Detroit's hand and the two start a joyful dance, ${ }^{18}$ soon joined by a crew of musicians, all of whom are clad in Victorian costumes, as well.

Before the notorious 1993 split, Sophie Muller managed to create one more music video for the band, this time for "Hello (Turn Your Radio On)," a clever take on Frida Kahlo's paintings. ${ }^{19}$ The next video she directed for them, the comeback "All the Queen's Horses" (2019), is an exercise in intertextuality ${ }^{20}$ revamping selected elements from the band's previous music videos. In an interview with Jedd Beaudoin, Fahey admitted that "[Muller]'s produced another masterpiece on a slender budget. And only she could have done it. She explored the struggle we had between ourselves and made it funny. It's sort of a sequel to the early videos." In the same interview, Detroit stated: "Only Sophie could have done that, understanding the dynamic between us and using that in the videos." According to Hanna Hanra, the video to "All the Queen's Horses"

tells their story: the ego struggle, the strained relationship, the paranoia; there's a sparkly catsuit, eye-rolls. The "Stay" video is recreated on a pool table.... The only difference to the story is that this time the two walk into the sunset arm in arm.

In this country-flavoured ballad of departure and reunion, Detroit and Fahey, dressed in cowboy garb, talk, argue, drink together, and show each other more or less rude gestures. Theirs is a rocky relationship, full of admiration and hatred at the same time. Drag queens impersonating "Stay" characters endow the video with an additional camp undertone. However, the ending is very uplifting, suggesting that despite their differences, both personal and

18 What encourages such an optimistic conclusion is the overall upbeat tempo of the song, with a rhythm section reminiscent of Tamla Motown productions.

19 Muller's music videos for "My $16^{\text {th }}$ Apology" and "Catwoman" are excluded from the analysis because they mostly rely on live footage.

20 In this case, intertextuality embraces the audial sphere, as well, the harmonica inviting comparison with Ennio Morricone's soundtracks to spaghetti westerns by Sergio Leone. Małgorzata Grajter emphasizes the importance of another musical element, i.e. the string orchestra, the aim of which is to form a lyrical counterpoint to the chorus melody, thus introducing a so-called "neoromantic" element. 
creative, they are able to talk to each other again. ${ }^{21} \mathrm{~A}$ Gothic conflict is thus deconstructed, allowing for an unlikely union between an oppressed damsel and her tormentor, these two roles ambiguously floating between them.

A similarly uplifting tone is present in Shakespears Sister's most recent song, "When She Finds You," a collaboration with Richard Hawley, promoting their 2019 Ride Again EP. This time Detroit and Fahey keep switching in their roles of a psychologist and her patient. The music video, typically for Muller aesthetics, merges Gothic quality, finesse and nostalgia for film noir. ${ }^{22}$ Some space is reserved for UFO sightings and the 1950s American sci-fi ambiance. Muller seems to play with the Cat-Women of the Moon concept that accompanied the production of Hormonally Yours. In a poignant final scene, Fahey goes through a series of UFO pictures/ drawings only to discover small-print writing under one of them: "You mean we could have been friends all of this time?", to which Detroit offers Fahey a serene smile. This obviously alludes to Baby Jane's climax, when, soon after Blanche's confession that she was to blame for the accident and Jane's resulting decline, Jane responds in disbelief: "You mean all this time we could have been friends?" A question like this serves as a perfect coda for several interconnected narratives of co-existing affection and rivalry, admiration and hatred, dependence and liberation, on both a personal and fictitious level.

The unexpected truce between Siobhan Fahey and Marcella Detroit has opened a new chapter in the complex history of their band. Their resumed collaboration with Sophie Muller is a promise of new Gothic-themed videos. Gary Ryan, in his interview with the band, states: "Art imitated life in their videos, which jokily telegraphed their rivalry and enmity towards each other," the two recent ones reflecting their newly found understanding, though. Music videos as such demonstrate similar interconnectedness and instability: "[they] ha[ve] . . . undergone shifts in technologies and platforms, periods of intense cross-pollination with other media, financial booms and busts, and changing levels of audience engagement" (Vernallis 207). The same could be written about Gothicism and its dependence on new media outlets, music video among them, that enabled its development and subsequent intertextuality. One may thus assume that the intertextual references to cinematic classics inspired by broadly understood Gothicism will remain an integral element of music video culture, as showcased by Shakespears Sister's musical and visual output.

21 For Fahey and Detroit, the video was more than just an illustration of their reconcilement, but also "making fun of [their] past selves" and showing "a sense of humour about [their] paranoia and insecurity" ("Here to 'Stay"?").

${ }_{22}$ The song is very nostalgic also music-wise, with clear references to the $1960 \mathrm{~s}$ sound, slower surf rock instrumental pieces in particular. Małgorzata Grajter highlights the role of the string orchestra to enhance that "retro" feel. 


\section{Works CiTED}

Blase, Cazz. "Song of the Day: Shakespears Sister-'Goodbye Cruel World." Thefword.org.uk. The F Word: Contemporary UK Feminism. 29 Dec. 2012. Web. 1 Mar. 2020.

Botting, Fred. Gotbic. London: Routledge, 1999. Print.

Cameron, Keith. "Queen Herald the Age of the Music Video." Theguardian. com. The Guardian 12 Jun. 2011. Web. 17 May 2020.

Cohan, Steven. Hollywood Musicals. London: Routledge, 2019. E-book. https://doi.org/10.4324/9781351018746

Detroit, Marcella. "FAQ. 5. Why did the band split up?" Marcella-detroit. com. Marcella Detroit 2016. Web. 1 Mar. 2020.

Detroit, Marcella. "Interview: Marcella Detroit-'I learned a lot about what it means to be an artist.' By Michael Hubbard." Musicomb.com. musicOMH 3 Aug. 2005. Web. 2 Mar. 2020.

Fahey, Siobhan. "Siobhan Fahey Talking to Mick Brown on the Night Network." Online video clip. YouTubecom. YouTube 1988. Web. 1 Mar. 2020.

Fisiak, Tomasz. "Grande Dame Guignol and the Notion of the Aftermath: A Case Study of Robert Aldrich's Hush ... Hush, Sweet Charlotte (1964)." Aftermath: The Fall and the Rise after the Event. Ed. Robert Kusek, Beata Piątek and Wojciech Szymański. Kraków: Wydawnictwo Uniwersytetu Jagiellońskiego, 2019. 319-29. Print.

Fisiak, Tomasz. "Hag Horror Heroines: Kitsch/Camp Goddesses, Tyrannical Females, Queer Icons." Redefining Kitsch and Camp in Literature and Culture. Ed. Justyna Stępień. Newcastle upon Tyne: Cambridge Scholars, 2014. 41-52. Print.

Fisiak, Tomasz. "What Ever Happened to My Peace of Mind? Hag Horror as Narrative of Trauma." Text Matters 9 (2019): 316-27. Print. https:// doi.org/10.18778/2083-2931.09.19

Graff, Gary. "Shakespears Sister Returns with Reunion EP Ride Again: Premiere.” Billboard.com. Billboard 24 Oct. 2019. Web. 20 May 2020.

Grajter, Małgorzata. Personal e-mail communication with the author. 7 May 2020.

Hanra, Hanna. "Shakespears Sister: 'I've been trying to mop up grudges, but this was a major one." Theguardian.com. The Guardian 21 May 2019. Web. 2 Mar. 2020.

Helmore, Edward. "II wouldn't sit on her toilet ...' Screen Revival of Davis and Crawford Feud Sparks Sexism Debate." Theguardian.com. The Guardian 19 Feb. 2017. Web. 3 Mar. 2020.

Hennessy, Brendan. "The Gothic Novel." British Writers. Volume 3. Ed. Ian Scott-Kilvert. New York: Scribner's, 1980. 324-46. Print. 
Khan, Imran. "Hormonal Rush: The Rise and Fall (and Rise Again) of Shakespears Sister.” Popmatters.com. Pop Matters 10 Apr. 2017. Web. 2 Mar. 2020.

Martin, Philip. W. "Nightmare." The Handbook to Gothic Literature. Ed. Marie Mulvey-Roberts. New York: New York UP, 1998. 164-65. Print. Parker, Lyndsey. "All's Well That Ends Well: Shakespears Sister's Epic Tale of Reunion and Redemption." Yaboo.com. Yahoo! Entertainment 31 Jul. 2019. Web. 20 May 2020.

Phelps, Gilbert. "Varieties of English Gothic.” From Blake to Byron. Ed. Boris Ford. Harmondsworth: Penguin, 1982. 110-27. Print.

Shakespears Sister. "Hello (Again) Cruel World: An Interview with Shakespears Sister. By Jedd Beaudoin.” Popmatters.com. Pop Matters 22 Aug. 2019. Web. 4 Mar. 2020.

Shakespears Sister. "Here to 'Stay'? '90s Pop Giants Shakespears Sister Didn't Talk to Each Other for 26 Years. Here's Their First Comeback Interview. By Gary Ryan.” Nme.com. NME 15 May 2019. Web. 5 Mar. 2020.

Shelley, Peter. Grande Dame Guignol Cinema: A History of Hag Horror from "Baby Jane" to "Mother." Jefferson, NC: McFarland, 2009. Print. Shore, Michael. The Rolling Stone Book of Rock Video. Quill: New York, 1984. Print.

Sontag, Susan. "Against Interpretation" and Other Essays. New York: Octagon, 1978. Print.

Straw, Will. "Music Video in Its Contexts: Popular Music and PostModernism in the 1980s." Popular Music 7.3 (Oct. 1988): 247-66. Print. https://doi.org/10.1017/S0261143000002932

Sunset Boulevard. Dir. Billy Wilder. Perf. William Holden, Gloria Swanson. Paramount Pictures, 1950. DVD.

Vernallis, Carol. Unruly Media: YouTube, Music Video, and the New Digital Cinema. Oxford: Oxford UP, 2013. Print. https://doi.org/10.1093/ac prof:oso/9780199766994.001.0001

What Ever Happened to Baby Jane? Dir. Robert Aldrich. Perf. Joan Crawford, Bette Davis. Warner Bros., 1962. DVD.

Tomasz Fisiak is Assistant Professor in the Department of Canadian, Intermedial and Postcolonial Studies, Institute of English Studies, University of Lodz. His book She-(d)evils? The Construction of a Female Tyrant as a Cultural Critique was published in 2020 by Peter Lang. Gothicism as a widely understood cultural phenomenon, as well as gender/queer/feminist issues, remain the main subjects of his research. His publications include articles on feminist auto/biographies, horror cinema in the 1960s and the 1970s, and modern erotic fiction. 
He is currently a team member of the project Word, Sound and Image: Intertextuality in Music Videos no. 2019/33/B/HS2/00131 financed by National Science Centre in Poland.

ORCID: 0000-0002-5514-1287

tomasz.fisiak@uni.|lodz.pl 